\title{
LAZISMU AND REMAKING THE MUHAMMADIYAH'S NEW WAY OF PHILANTHROPY
}

\section{Zakiyuddin Baidhawy}

State Institute of Islamic Studies (IAIN) Salatiga

email: sbaidhany@gmail.com

\begin{abstract}
This study is aimed to analyze the new way of philanthropy by special reference to Lembaga Amil Zakat Infak dan Sadaqah Mubammadiyah (Mubammadiyah Philanthropic Board: hereafter Lazismu); explore the measures taken by Lazismu to promote empowerment and social justice movements by combining charity and entrepreneurship; and understand the motive of the new philanthropy movement initiated by Lazismu. Through the 'third way' approach and analysis, this study found that: first, Mubammadiyah, as a non-profit social-religious organization, admits its role as an agent of transformation vis-à-vis the State. Lazismu is able to show its flexibility to adapt to new trends in philanthropy. Lazismu is also able to initiate breakthrough in management of Zakat, Infaq, and Sadaqah and move them beyond charity activities to productive and redistributive activities to promote social justice and equity. Second, Lazismu shows creativity and sophisticated programs exceeding the expectations of muzakeki (alms payer), benefactor, and donors. Realization of philanthropy programs developed by Lazismu extends from education development, agriculture development, youth entrepreneurship, and women empowerment, to Masjid based community empowerment. Third, Lazismu combines theology of love, generosity, and voluntarism to produce transformative philanthropy that is successful to alter charity oriented generosity to creative and innovative good deeds.

Kajian ini dimaksudkan untuk melibat model filantropi baru pada Lazismu (Lembaga Amil Zakat Infake dan Sadaqah Mubammadiyah);
\end{abstract}


mengungkapkan langkah-langkah yang diambil oleh Lazismu untuk melakukan pemberdayaan dan keadilan sosial; dan untuk memahami tujuan filantropi baru yang digagas oleh Lazismu. Menggunakan pendekatan dan analisis "Jalan Ketiga", makalah ini menemukan bahwa Muhammadiyah, sebagai organisasi non-profit, mengakui perannya sebagai agen perubahan visa-vis Negara. Laqismu mampu menujuk.kan fleksibilitas untuk beradaptasi dengan mode-mode filantropi baru. Lazismu juga mampu menemukan terobosan-terobosan dalam manajemen zakat, infak, dan sedekah. Lazismu mengelolanya dari sekedar kegiatan kedermawanan menjadi kegiatan-kegiatan produktif dan redistributif untuk mewujdukan kesetaraan dan keadilan sosial. Kedua, Lazismu menunjukean kreatifitas dan program-program canggih melampaui harapan muzakeki, donor, dan penerima. Wujud program filantropi yang dikembangkean oleh Lazismu meliputi pengembangan pendidikan, pembangunan pertanian, kewirausahaan pemuda, dan pemberdayaan perempuan, sampai dengan pemberdayaan masyarakat berbasis masjid. Ketiga, Lazismu mengkombinasikan teologi kasib, kebajikan, dan kerelawanan, untuk mewujudkan filantropi transformatif yang berhasil mengubah kebajikan berorientasi amal menjadi program-program kreatif dan inovatif.]

Keywords: creative-innovative philanthropy, socialjustice, Lazismu, Muhammadiyah

\section{A. Introduction}

Muhammadiyah was born with three identities, namely tajdid (reform), da'wa amr ma'rüuf (promoting good), and naby munkar (preventing evil) movements. Tajdid movement was inspired by the teachings of Prophet Muhammad on the importance of having a reformist to revitalize religion at every course of history and civilization. The amr ma'rüf and naby munkar movement is a commitment to implement the Qur'anic teachings on the responsibility of groups of the umma (community) to promote good and prevent evil in order to attain happiness and welfare. ${ }^{1}$

The vital force of this movement is the al-Ma's $\bar{u} n$ theology. Muhammadiyah manifest the spirit of $a l-M \bar{a}^{6} \bar{u} n$ in three different grounds

${ }^{1}$ See Anggaran Dasar Muhammadiyah, Chapter II on its Identity, Foundation, and Symbol, article 4, verse 1: "Muhammadiyah adalah Gerakan Islam, Da'wah Amar Ma'ruf Nahi Munkar dan Tajdid, bersumber pada Al-Qur`an dan As-Sunnah," "Anggaran Dasar Pimpinan Pusat Muhammadiyah", Muhammadiyah.or.id, http://www. muhammadiyah.or.id/id/content-51-det-anggaran-dasar.html, accessed 31 Oct 2015. 
of civilization: schooling, healing, and feeding. ${ }^{2}$ The first is manifested in the ever growing field of education, the second is shown through the continuous development of healthcare services and healthcare facilities to serve human kind regardless of religion, ethnicity, and culture; and the last one is evident in the development of charity based social services across the country.

The three continue to light the nation with no sign of decline. ${ }^{3}$ There are many Muslim and Non-Muslim organizations that follow the steps of Muhammadiyah in building civilization in the three grounds. Muhammadiyah's reform in the first century through the intellectual enlightenment of the nation (schooling), health care (healing) through "Penolong Kesengsaraan Oemoem" (PKO Hospital), and empowering the poor has become the common belongings of the nation. Other religious movements and civil society also developed the same things of various school models, orphanages, and empowerment of the poor, and health-care agencies. ${ }^{4}$

\section{B. New Approach in Philanthropy}

At the moment, in its second century, Muhammadiyah steps forward to open new spaces in their devotion to the public and their role in civilization. What Muhammadiyah initiates intertwines with global progress. The global civil society movements strive to show their new role and social functions. This is what has been described by experts as the "new" and "third way" of philanthropy. ${ }^{5}$ Muhammadiyah demonstrates

${ }^{2}$ Ahmad Najib Burhani, "Makna Teologi al-Ma'un di Dua Generasi Muhammadiyah", Suara Mubammadiyah, vol. 13, no. 98 (2013), p. 34.

${ }^{3}$ Hajriyanto Y. Thohari has noted that Muhammadiyah is known through three movements in education, health and social services, and these movements continue to run and take off. Now, in the 2nd century Muhammadiyah is going to move the new trident, namely Muhammadiyah Disaster Management Center (MDMC), Council for Community Empowerment (Majelis Pemberdayaan Masyarakat), and Muhammadiyah Philantrhropic Board (Lembaga Amil Zakat Infak dan Sadaqah Muhammadiyah, Lazismu). See Hajriyanto Y. Thohari, "Trisula Baru Gerakan Muhammadiyah", in Abdul Mu'ti et.al. (eds.), Kosmopolitanisme Islam Berkemajuan (Surakarta: Muhammadiyah University Press, 2016), pp. 329-333; See also Azaki Khoirudin, "Trisula Baru Muhammadiyah", Kedaulatan Rakyat, 15 July 2015.

${ }^{4}$ Benni Setiawan, "Trisula Abad Kedua”, SINDOnews.com (4 Aug 2015), http:// nasional.sindonews.com/read/1029056/18/trisula-abad-kedua-1438651728, accessed 31 Oct 2015.

${ }^{5}$ See for examples Tony Blair, Private Action, Public Benefit: A Review of Charities and the Wider not-for Profit Sector (London: Cabinet Office Strategy Unit, 2002); Nicholas Al-Jämi'ah, Vol. 53, No. 2, 2015 M/1437 H 
this new public role through the establishment of Lazismu (Lembaga Amil Zakat Infak dan Sadaqah Muhammadiyah or Muhammadiyah Philanthropic Board.

This trend intertwines with the publication on welfare reform and social entrepreneurship. Giddens in his seminal work The Third Way and Its Critics, shows the trajectory of discussion from "the third way" for various movements that were born after World War II, that were later brought to United States and United Kingdom by Democratic Party and Labor Party in the 1990s. ${ }^{6}$ The bone of this movement is new progressivism that fights for equal opportunity, personal responsibility, and community activism. The idea that "rights come with responsibilities" limits the government to focus more on creation of new welfare instead of redistribution. This way of thinking originated from the traditional left perspective that tends to see that the harm of the market may be solely addressed by the government. Giddens asserted that this new approach is interesting for them who criticize the government for intervening too much, but who hold their left values very strongly. ${ }^{7}$ Hale relates the third way with the administration of Bill Clinton and Tony Blair in 1992 and the efforts for social democracy in Europe as seen in Germany, French, and Scandinavian countries. ${ }^{8}$ The followers of the third way tried to incorporate and disseminate "social values" instead of individual values promoted by the new right movement. What is new about this movement is the focus on economic efficiency for social justice. Blair stated that the third way is a reorganization of history of effective economic, social, and market policy to build successful modern economy. In the case, formulation of proper role of the political system is directed to help individual to succeed through education and training. ${ }^{9}$

Deakin, "Putting Narrow-Mindedness Out of Countenance: The UK Voluntary Sector in the New Millennium", Civil Society Working Paper 4 (January 2000), http:/ / eprints.lse. ac.uk/29034/1/cswp4.pdf, accessed 31 Oct 2015.

${ }^{6}$ Anthony Giddens, The Third Way and its Critics (Cambridge: Polity Press, 2000), p. 144 ,

${ }^{7}$ See Andrea Grove and Gary A. Berg (eds.), Social Business Theory, Practice, and Critical Perspectives (Camarillo, CA California Institute for Social Business California State University Channel Islands, 2014), p. 8.

${ }^{8}$ Sarah Hale, Will Leggett, and Luke Martell (eds.), The Third Way and Beyond: Criticisms, Futures and Alternatives (Manchester: Manchester University Press, 2004).

9 Tony Blair, The Third Way: New Politics for the New Century (London: The Fabian Society, 1998); Tony Blair, Ken Coates, and Michael Barratt Brown, Third Way ... Where to? (Nottingham: Spokesman for Socialist Renewal, 2001); Flavio Romano, "Clinton and Blair: The Economics of the Third Way", Journal of Economic and Social Policy, vol. 
In Forces for Good: The Six Practices of High-Impact Nonprofits, Crutchfield mentioned that there is a tendency for non-profit organizations to be "agent of change." 10 He undermined non-profit organizations that act like business institutions, but supported these organizations to utilize the strength of business model. The Egger's work Begging for Change: The Dollars and Sense of Making Nonprofits Responsive, Efficient, and Rewarding for All emphasized that the importance of using business approach to run non-profit organizations began in mid 1900s during economic and technological explosion. ${ }^{11}$ Managers from profit organizations came to work for non profit organizations and brought the business approach with emphasis on measurable results, donors as investors, and capacity building. Similarly, in The End of Charity: Time for Social Enterprise, Frances provided explanation on personal experience in establishing NRG Cool. ${ }^{12}$ Frances argues that the traditional division between charity and entrepreneurship should be abandoned. Frances defined social entrepreneurship as a decent use of market value to identify problems, understand cost and benefit of solution, and sell benefit with the value that is larger than the cost. Foster, Kim and Christiansen argue that leaders of non-profit organizations are more sophisticated in developing programs compared to their donors, and benefactors should struggle to understand the impact of their contribution. ${ }^{13}$

"Social entrepreneurship" is a dynamic process where certain individuals, worth to be called social entrepreneur, create and develop organization that can be defined as "social business". ${ }^{14}$ However, the use of a definition or term more often than not depends on the focus

10, no. 2 (2006), pp. 79-94.

${ }^{10}$ Leslie R. Crutchfield, Forces for Good: The Six Practices of High-Impact Nonprofits (San Francisco: Jossey-Bass, 2012), pp. 79-94.

${ }^{11}$ Robert Egger, Begging for Change: The Dollars and Sense of Making Nonprofits Responsive, Efficient, and Rewarding for All (New York: Harper Collins, 2004).

${ }^{12}$ Nic Frances, The End of Charity: Time for Social Enterprise (Crows Nest: Allen \& Unwin, 2008); Tuti Alawiyah, "Religious Non-Governmental Organizations and Philanthropy In Indonesia", Indonesian Journal of Islam and Muslim Societies, vol. 3, no. 2 (2013), pp. 203-21.

${ }^{13}$ William Landes Foster, Peter Kim, and Barbara Christiansen, "Ten Nonprofit Funding Models”, Stanford Social Innovation Review, vol. 7, no. 2 (2009), pp. 32-9.

${ }^{14}$ Jacques Defourny and Marthe Nyssens, "Conceptions of Social Enterprise in Europe: A Comparative Perspective with the United States", 8th ISTR International Conference and 2nd EMES-ISTR European Conference (Barcelona, 2008); Johanna Mair and Ignasi Martí, "Social Entrepreneurship Reserach: a Source of Explanation, Prediction and Delight", Journal of World Business, vol. 41, no. 1 (2006), pp. 36-44. 
and/or the understanding of phenomenon related to certain contexts and perspectives. To put it shortly, "social entrepreneurship" is utilized in wider understanding which covers innovative social initiatives, from profit organizations to volunteer non-profit organizations.

One of the prominent texts in this field is Entrepreneurship in the Social Sector. ${ }^{15}$ The authors of this book defined social entrepreneurship as "activities of creating social and innovative values within non-profit sectors, business, or government sectors." This book demonstrates that the origin of social entrepreneurship movements in non-profit organization and charitable institutions are to control cost, improve income, and increase effectiveness. The authors argued that the combination between social and commercial approach produces uniqueness of management of challenges and opportunity worthy of learning.

Studying on social entrepreneurship grow faster in the UK and the US compared to Europe in general. The Anglo-Saxon tradition focuses on commercialization of non-profit sectors and private initiatives to improve community welfare. The European tradition focuses more on collective entrepreneurship and analysis at the level of organization. ${ }^{16}$ However, in the last years, the regional differences faded due to better dialogue between the two traditions facilitated by series of academic events such as the Social Entrepreneurship Research Colloquium. ${ }^{17}$

Although the debate continues, one of the definitions commonly used is one coined by Dees that social entrepreneurship plays the role of agent of change at social sector by means of 1) adopting mission to create and preserve social values; 2) admitting and continuously pursuing new opportunities to serve the mission; 3 ) engaging in the process of

${ }^{15}$ Jane Wei-Skillern et al., Entrepreneurship in the Social Sector (Los Angeles: SAGE Publications, 2007).

${ }^{16}$ Defourny and Nyssens, "Conceptions of Social Enterprise in Europe"; Janelle A. Kerlin, "Social Enterprise in the United States and Europe: Understanding and Learning from the Differences", Voluntas: International Journal of Voluntary and Nonprofit Organizations, vol. 17, no. 3 (2006), pp. 246-62.

${ }^{17}$ Sophie Bacq and Frank Janssen, "The Multiple Faces of Social Entrepreneurship: A Review of Definitional Issues Based on Geographical and Thematic Criteria", Entrepreneurship \& Regional Development, vol. 23, no. 5-6 (2011), pp. 373-403; J. Defourny and M. Nyssens, "Conceptions of Social Enterprise in Europe: A Comparative Perspective with the United States", 8th ISTR International Conference and 2nd EMES-ISTR European Conference (Barcelona, 2008); J. A. Kerlin, "Social Enterprise in the United States and Europe: Understanding and Learning from the Differences", Voluntas: International Journal of Voluntary and Nonprofit Organizations, vol. 17, no. 3 (2006), pp. 246-62. 
sustainable innovation, adaptation, and learning; 4) acting courageously regardless of the means and resources available, and; 5) demonstrating high accountability towards constituent and for results produced. ${ }^{18}$

Nicholls and Cho identify three main principles of social entrepreneurship namely: sociality, innovation, and market orientation. The first dimension, sociality, refers to the social and environmental focus of social entrepreneurship. This focus is able to be identified through inventions of public goods and positive externalities. The six fields inherent in social entrepreneurship initiatives include: 1) health and welfare services; 2) education and training; 3) economic development; 4) disaster relief and international aid; 5) social justice and political change; 6) planning and management of the environment. ${ }^{19}$

With regards to the second characteristics of social entrepreneurship, innovation, it is interesting to note that social entrepreneurship approach has a lot in common with commercial entrepreneurship model. For example, in several cases, the Schumpeter idea on the process of creative destruction that alter system and reorganize market to build new economic balance can also be found in social entrepreneurship initiatives, through incremental changes at micro level or through intervention at the level of system. ${ }^{20}$

Third, market orientation is manifested in various ways. Mostly, it is manifested in a form of non-profit social business that operates in commercial market and generates profits to be invested in social mission. ${ }^{21}$ Defourny and other writers from EMES network show that social business, unlike NGO or traditional non-profit organizations, produces goods and services and takes economic risks including bankcruptcy. Engaging volunteers and workers that are paid with minimum wage is

${ }^{18}$ J. Gregory Dees, "The Meaning of 'Social Entrepreneurship," reformatted and revised, May 30, 2001. https://centers.fuqua.duke.edu/case/wp-content/uploads/ sites/7/2015/03/Article_Dees_MeaningofSocialEntrepreneurship_2001.pdf.

${ }^{19}$ Alex Nicholls and Cho H A., "Social Entrepreneurship: The Structuration of a Field", in Social Entrepreneurship: New Models of Sustainable Change, ed. by Alex Nicholls (Oxford: Oxford University Press, 2008), pp. 99-118.

${ }^{20}$ Roger L. Martin and Sally Osberg, "Social Entrepreneurship: The Case for Definition", in Stanford Social Innovation Review (Leland Stanford Jr. University: Spring, 2007), pp. 29-39.

${ }^{21}$ S.K. Alter, "Social Enterprise Models and Their Mission and Money Relationships", in Social Entrepreneurship: New Models of Sustainable Social Change, ed. by Alex Nicholls (New York: Oxford University Press, 2006), pp. 205-32; Hilman Latief, "Islamic Philanthropy And The Private Sector In Indonesia", Indonesian Journal of Islam and Muslim Societies, vol. 3, no. 2 (2013), pp. 175-201. 
the signature character of social enterpreneurship.

In 2000, Fowler mentioned three types of social entrepreneurship, namely 1) integrated entrepreneurship, when economic activities produce social achievements; 2) modified entrepreneurship, when the non-profit business increase earnings; and 3) complementary entrepreneurship, when the commercial earnings subsidize the achievement of the social missions of the non-profit organization. ${ }^{22}$

\section{Lazismu Welcomes the New Atmosphere}

Lazismu was born at the beginning of 21 st century in 2002 . Its establishment was interpreted as the preparedness of Muhammadiyah to be the mujaddid (reformist) of the new century. The new ijtihasd follows the first ijtiha $\bar{d}$ which focused on extension of a more progressive and advance space or public sphere. The spirit of new al-Mä'un admitted by Lazismu is inspired by the passion to promote social justice, human development, and alleviation of poverty, ${ }^{23}$ that are still very far from happening in the constellation of both social and political vision and reality of this Nation-State.

This institution addresses contemporary issues and problems strangle Indonesians in general, and Muslims in specific. Poverty, social marginalization, decline in quality of human resources, and social injustices are some of the undeniable situations that happen in the midst of reviving development of the country and positive economic growth. ${ }^{24}$

In this situation, Lazismu carries mission to reform welfare. Welfare does not only mean material and economic growth, most importantly it means humanizing human, treating human with dignity, provide decent living for every citizen, and uphold social justice. The welfare reform lies on the generosity embedded in the Muslim community. This institution utilizes the potential of zakat, infaq, waqaf, and other philanthropic donations provided by individual, collective, or institutional and utilizes them for the purpose of problem solving social problems. ${ }^{25}$

${ }^{22}$ Alan Fowler, "NGDOs as a Moment in History: Beyond Aid to Social Entrepreneurship or Civic Innovation?”, Third World Quarterly, vol. 21, no. 4 (2000), pp. 637-54.

${ }^{23}$ Lembaga Amil Zakat Infaq dan Shadaqah (Lazismu) Pimpinan Pusat Muhammadiyah, Memberi untuk Negeri: Annual Report 2010-2014 (Yogyakarta, PP Muhammadiyah, 2010), p. 8.

${ }^{24}$ Ibid.

${ }^{25}$ Ibid. 
Referring to Gidden's analysis above, Muhammadiyah through Lazismu opens new hope for justice and equity. The welfare and social justice as the goals are truly supported by social entrepreneurship. Lazismu initiates breakthrough in managing zakat, infaq, and sadaqah by treating them not only as charitable activities, but most importantly as productive and redistributive activities. ${ }^{26}$ These activities are designed to prevent Lazismu from becoming passive distributor of donation. Instead, Lazismu is working to achieve self-sufficiency while performing its traditional role as collector and distributor of zakat, infaq, and sadaqah. The work to achieve self-sufficiency is manifested through the establishment of social business in producing larger social welfare. ${ }^{27}$ This way, in line with Gidden, Muhammadiyah is able to preserve their identity as civil society organization that is independent from the influence of the "noisy" State and may even provide alternative solution for the failure of the State to improve the dignity and welfare of their citizen. Gidden refers this role as an agent of transformation. In other words, Muhammadiyah is performing the naby munkar role against the State in peaceful and non-violent manners.

The characteristics of new philanthropy of Lazismu are evident in its loyalty and devotion to social values amāna, professional, and transparency. ${ }^{28}$ Lazismu was established with complete realization to utilize this institution as an instrument to manifest the values of Islam in order to achieve the true Islamic community; Balda tayyiba, welfare state that is showered with abundant blessings and mercy of Allah.

Inspired by the spirit of Islam as rabma li al-'álamin (kindness and love for all), organization and management of financial resources and other resources are based on the principle of "amàna". Amāna means two folds. ${ }^{29}$ First is acknowledgement of the responsilibility bestowed by Allah to prosper the earth. This definition signals that managing zakat, infaq, and sadaqah is part of spiritual devotion to God that will be rewarded in the hereafter. Second is acknowledgement of the responsibility to

${ }^{26}$ Hilman Latief, Aksi Bersama untuk. Sesama: Perilaku dan Potensi Filantropi Warga Muhammadiyah (Yogyakarta: LP3M UMY, Program Studi Muamalah, Ekonomi dan Perbankan Islam Fakultas Agama Islam UMY \& Lazismu, 2015), pp. vi-viii.

${ }^{27}$ See Hilman Latief, Melayani Umat: Filantropi Islam dan Ideologi Kesejabteraan Kaum Modernis (Jakarta: PT Gramedia Pustaka Utama, 2010), pp. 242-49.

${ }^{28}$ Lembaga Amil Zakat Infaq, Memberi untuk Negeri p. 8.

${ }^{29}$ Wahbah al-Zuhayli, al-Tafsìr al-Munir fi al-'Aqidah wa al-Shari'ah wa al-Manhaj (Beirut: Dār al-Fikr, 1991), vol. 18, pp. 9-13; A ḥmad Musțāfāa al-Marāghī, Tafsìr al-Marāghì (Beirut: Dār al-Fikr, 1994), vol. 18, pp. 192-193. 
distribute the zakat, infaq, and sadaqah paid by the benefactors in a fair manner. This responsibility is performed entirely as service to humanity and is devoted to humanity. Fortune, money, wealth, and waqf received by Lazismu are not only distributed to the mustabiq (the entitled ones), but also are managed in such a way to ensure the sustainability of the utilization of the funds from zakat, infaq, and sadaqah. Management of the institution is required to be able to empower the mustabiq (entitled ones/people who are entitled to receive zakat) to become murakei. (zakat payer) and empower the humanity in general. This is part of the social devotion instilled by Amāna. Hence, Lazismu support embodiment and implementation of the value of trust from and to God, and trust to the humanity. The leaders of this institution understand that amāna is both spiritual (ukhrawi) and social (mu'amala). The success of the management of the institution can be seen from the perspective of devotion to God and devotion to the community and as a consequence of the implementation of amāna principle, the benefactors may generate continuous reward ('amal jariya) out of their zakat, infaq, and sadaqah.

Amana is not only internalized as the organizational culture, but at the same time also become the orientation of the staffs. The detailed description of the value/principle of amana includes professionalism and transparency. Professionalism means that Lazismu build, grow, and develop knowledge and skill of the staffs to collect, produce, consume, and distribute zakat, infaq, sadaqah funds. Professionalism is shown in the process of planning, implementation, and evaluation of the philantrophic programming. ${ }^{30}$

Transparency in managing philantrophic funds is manifest through publication of annual report that is accessible to related institutions. In order to realize professionalism and transparency, Lazismu is also equipped with wali amana (board of advisory), shari'a board, supervisory board, and executive body. Furthermore, the report will be presented and will also be hold accountable at the Tanwir assembly and Muktamar Muhammadiyah (Muhammadiyah General Assembly) to allow the stakeholder of the organization to read, understand, and criticize the organization. ${ }^{31}$

The value of amana in Lazismu is also manifested in a form of professional responsibility and transparency in the utilization and management of philantrophic funds. As amil institution, Lazismu has the

${ }^{30}$ Khoirul Muttaqin, interview (28 Jun 2015).

${ }^{31}$ Ibid. 
right and opportunity to use at most $20 \%$ of the zakat, infaq, sadaqah, and other donations trusted to them. Over the course of 13 years of its operation, Lazismu only utilizes at most 12,5\% of the total funding received from the benefactors. ${ }^{32}$ This amount is utilized to manage the institution and organize assets to ensure proper and just distribution of funds to the designated targets through surveys and field observations.

The face of new philanthropy of Lazismu is evident in the sophistication of this institution in creating programs which exceed the expectations of Murakeki, benefactors, donors, and corporate social responsibility of the contemporary companies that serve as donors as well. The idea of Egger explained above earned its realization in the philantrophic programs developed by Lazismu. Generally the Lazismu programs include economy and agriculture, human resource development, and social humanity and religious empowerment. ${ }^{33}$

Human resource development program, especially education development, includes several key activities such as Save Our School, foster parent movement (gerakan orang tua asub) and Trensains. Save Our School is inspired by the reality that there are a total of 899,016 of Public Elementary School across Indonesia according to the data released by the government in 2011. Out of this number, there are around 110,598 schools that are damaged. ${ }^{34}$

The following is the description of the education development programs. First, Save Our School program is explained in activity referred to as Integrated Development for Education (IDE). It is a program dedicated to develop marginalized schools into favorite school through implementation of integrated system which combine development of facilities with disaster mitigation standard (against earthquake, flooding, and fire for instance), development of disaster risk reduction curriculum, improvement of the quality of teaching staffs, and provision of scholarships. The movement began in 2010 with the implementation of the program in Muhammadiyah 10 Elementary School in Pancoran Mas, City of Depok, West Java. This movement began as improvement of education program that has been implemented since

${ }^{32}$ Ibid.; Latief, Aksi Bersama untuk Sesama, pp. 53-5.

${ }^{33}$ Lembaga Amil Zakat Infaq, Memberi untuk Negeri, pp. 39-43.

34 “110 Ribu Ruang Kelas SD Kondisinya Rusak Berat", RMOL.co (6 Dec 2012), http://www.rmol.co/read/2012/02/12/54577/110-Ribu-Ruang-Kelas-SDKondisinya-Rusak-Berat-, accessed 31 Oct 2015. 
2002. ${ }^{35}$ The realization of this program Save Our School during 20092015 has comprised 6 disaster safe schools, 4 creative school, and facilities renovation for 226 schools. ${ }^{36}$

The second one is Foster Parent Movement. This program is a social welfare program that aims to ensure continuity of the education of orphans and students from poor family through foster care. This movement is not only directed towards provision of material or financial support for the continuity of education, but most importantly, it is also focused on creation of "loving bond" between foster children and foster parents through intensive communication. The National Foster Parent Movement is established as collaboration between Lazismu and Child Center Indonesia (CCI) with the support of CSR of Danamon Shari'a Bank to help community channel their social concern in an effective and targeted manner. ${ }^{37}$

The Foster Parent Program includes: 1) National Foster Parent Movement that provides scholarship for poor orphans and children at Elementary School through Foster Care model; 2) each foster child will get one foster parent to support their education for one year with possible extension; 3) each foster parent can have more than one foster child; 4) each foster parent is granted access to communicate to the foster child so that they can follow the progress the child/children that they support; 5) Lazismu and CCI bridge foster parents and foster children. Lazismu and CCI organize meetings between foster parent and foster child through series of activities. The implementaion of the Foster Parent Movement (2002-2015) consists of 2890 student scholarships and 72 foster children. ${ }^{38}$

The third is the latest initiative from Lazismu in the field of education, called Trensains. Trensains is an acronym for Pesantren Sains (Islamic Boarding School for Scientific Education). Trensains is

35 The IDE Program is implemented by integrating 1) renovation and development of school facilities, 2) improvement of teaching and learning facilities, 3 ) improvement of quality of education system, 4) improvement of quality of teaching staffs, 5) provision of books, 6) scholarship for students from poor family, 7) standardization of school building using disaster mitigation standard, 8) implementation of Disaster Risk Reduction Curriculum at school, and 9) "Save our School" campaign to raise public awareness to support marginalized school with limited facilities to advance by integrating renovation of school and school facilities, development of education system, improvement of quality of teaching staffs, and provision of scholarship in one program cycle.

${ }^{36}$ Lembaga Amil Zakat Infaq, Memberi untuk Negeri, pp. 44-5.

${ }^{37}$ Ibid.

${ }^{38}$ Ibid. 
a synthesis of Islamic Boarding School and High School focusing on scientific education. Trensains is an education institution at the level of High School that is acknowledged as a breakthrough both in Indonesia and the Islamic world. Its main activities is studying and conducting research on verses on the universe in the Quran and Hadith. The leading inspiratory of this program is Agus Purwanto (Physicist Alumni of Hiroshima University, Japan). The earliest Trensains program was established in District of Sragen, Central Java Province by the name of SMA Trensains DIMSA (Darul Ihsan Muhammadiyah Sragen)/ DIMSA Trensains High School. The institution was established on 1 Muharram 1435 H/ 5 November 2013 by Muhammadiyah Head Office. The second Trensains for kinder garden has been established in Ciputat, South Tangerang. And this program also runs 20 workshops and TOT Trensains for teacher \& students. One of the uniqueness of this initiative is that it is also opened in Tebuireng Islamic Boarding School in the District of Jombang, East Java Province that is owned by NU. This signals that Muhammadiyah is open to collaborate with any institution at all to develop education that promotes rabma li al-'álamin (kindness and love for all). ${ }^{39}$

The second program is agriculture empowerment called through "Tani Bangkit" (Farmer Revive). This program is inspired by the devastating condition of farmers in Indonesia. Community farming, including food farming, is experiencing leveling-off and systematic and massive impoverishment. No matter how much input provided, the production remains stagnant. At the same time, the increase in the price of seed and rice is not able to alleviate farmers from poverty. Farmers cultivating non-rice products also experience decline. Impoverishment of farmers is more often than not structural in its nature. Government policy in agriculture is made behind the desk without looking deeper into the actual problems and the objective situation of farmers and national farming. In addition to misleading policies, farmers are also exposed to problems of market governance, marketing, distribution, and other problems. Most farmers are as consequence vulnerable to exploitation committed by major corporations of farming production facilities such as fertilizer, pesticide, seed, and marketing of farming products. ${ }^{40}$

In the meantime, ownership of land also decline. This situation is deteriorated by the decline in fertility of the land. Our farmers are

${ }^{39}$ Ibid., pp. 40.

${ }^{40}$ Ibid., pp. $40-5$. 
also left very much behind in terms of farming skills compared to farmers around the world. Bank and other financial stakeholders are also reluctant to support farmers and farming. Based on the abovementioned situation, Tani Bangkit program in more than 24 areas in Indonesia is initiated to empower farmers. Because strong and well organized farmers' organization will be able to tackle problems of the farmers. Strong and solid Farmers organization will be able to facilitate meetings and discussions to solve problems that they are facing and look for best solutions. $^{41}$

Empowerment is one of the manifestations of al-Mác'in theology. It is an awareness and social praxis to allow the weak to stand strong and be self reliant. Muhammadiyah is known as an organization that was supported by religious leaders who are also traders and merchants, well known for their independency. Muhammadiyah grew at the centers of economic activities including at the center of Batik in Pekajangan, Pekalongan, Kotagede Yogyakarta, City of Padang, and City of Solo to name a few. ${ }^{42}$ The passion for entrepreneurship enforces Muhammadiyah financial and intellectual independence.

Muhammadiyah from the beginning of its establishment until the 1950s, as mentioned by Geertz, was supported by leaders, members, and supporters with passion for business. ${ }^{43}$ Nakamura also observed similarly. The bottom line is that the basis of the members of Muhammadiyah at that time was traders and merchants communities. ${ }^{44}$

In line with the development and modernization of education, Muhammadiyah generated many intellectuals. The growth of differentiation of social functions promotes growth of new fields of work following the ever increasing compartmentalization of knowledge. On the basis of link and match, graduates from Muhammadiyah

${ }^{41}$ Ibid.

${ }^{42}$ James L. Peacock, Purifying the Faith: the Muhammadijah Movement in Indonesian Islam (California: The Benjamin/Cumming Publishing Company, 1978), p. 110; Irwan Abdullah, The Muslim Businessmen of Jatinom: Religious Reform and Economic Modernization In a Central Javanese Town, Ph.D Dissertation, (Amsterdam: Universiteit Van Amsterdam, 1994); Masmulyadi, "Muhammadiyah dan Rekonstruksi Mental Entrepreneurship", khittah.co, http://www.khittah.co/muhammadiyah-dan-rekonstruksi-mentalentrepreneurship/1327/, accessed 31 October 2015.

${ }^{43}$ Clifford Geertz, The Religion of Java (Chicago: University of Chicago Press, 1976).

${ }^{44}$ Mitsuo Nakamura, The Crescent Arises Over the Banyan Tree: A Study of the Muhammadiyah Movement in a Central Javanese Town, C.1910-2010 (Singapore: Institute of Southeast Asian Studies, 2012). 
Lazismu and Remaking the Muhammadiyah's New Way of Philanthropy schools and other schools compete for position in various fields of development. The changing mindset about social honor and its relation to employment began to shift the basis of Muhammadiyah from merchants to government employees and/or private and Muhammadiyah employees.

Most of the elites leading Muhammadiyah from the level of Head Office to Sub District Office work as civil servants. Leaders like Ahmad Syafii Maarif, Din Syamsuddin, Amin Abdullah, Abdul Munir Mulkhan, Dasron Hamid, A. Rosyad Sholeh, M. Amien Rais, and other prominent leaders of Muhammadiyah are civil servants or retired civil servants. On the one hand, considering strong ties of Muhammadiyah leaders to universities, science and knowledge serve as the new power of Muhammadiyah in haraka al-ilm. Leaders and members of Muhammadiyah at the universities across the country are resources necessary to realize this vision. On the other hand, transformation of merchants and traders to government and private employees cost Muhammadiyah their entrepreneurship basis. ${ }^{45}$

Muhammadiyah therefore considers that it is important to revive the puritans and entrepreneurship ethos to mobilize organization and the communities. Muhammadiyah believes that the traders' ethics can be instilled and developed through improvement of knowledge, skill, and passion for business to produce strong leaders in business and entrepreneurship. Lazismu, therefore, develop program of Youth Entrepreneurship which organizes and supports 15 groups and 180 young enterpreneurs. ${ }^{46}$

One of the identities of Muhammadiyah is da'wa amar ma'ruf naby munkar (Islamic propagation). All programs and activities commited by Muhammadiyah are implemented in the context of Islamic propagation, spreading peace, and bringing welfare to all humankind. The forefront of $\mathrm{da}$ 'wa is dai (person who propagates Islam). Dai inherits the struggle of Prophet Muhammad PBUH to spread Islam. Following the teaching of Islam, dai is categorized as one of the groups who fight for the sake of God. Hence, their livelihood and wellbeing shall be guaranteed by Islamic Philantropy through zakat, infaq, and sadaqah since dai is also one of the eight groups of Muslim community entitled to benefit from zakat.

The Indonesian archipelago from Sabang to Merauke, which part of the areas are the outermost of the country and rarely touched

${ }^{45}$ Ahmad Fuad Fanani, "Muhammadiyah Sebagai Gerakan Ilmu", Republika (18 May 2010).

${ }^{46}$ Lembaga Amil Zakat Infaq, Memberi untuk Negeri, pp. 40-5. 
by development facilities, provide opportunity to Islamic propagation (da'wa) and dai. Therefore, providing for the dai and empowering them is one of the obligations of the ummah as part of enforcing Islamic propagation in every part of the country. Implementation of Dai Mandiri Program (2003-2015) consist of sending 654 dais to remote hinterland and training for 300 dais. This obligation is also manifested in a form of Masjid based empowerment, development of micro finance institution by establishing 116 Bayt al-Mäl Muhammadiyah, and qard al hasan capital installment to the Bayt al-Tamwil. ${ }^{47}$

Comprehensive empowerment utilizes every opportunity available to improve the wellbeing and welfare of the community. The independent dā'i and the youth entrepreneurship mostly target male beneficiaries. Hence, Lazismu consider expanding their programs to include more female beneficiaries through special initiative entitled "Perempuan Berdaya" (Women Empowered). This program is a women empowerment movement through family based economic development. The program targets women and mothers as beneficiaries because of their patience and perserverance and most importantly because they are reliable source of family income. The initiative was manifested through "Bina Usaha Ekonomi Keluarga" (BUEKA)/Business Facilitation for Family Economy program. ${ }^{48}$

In collaboration with Head Office of Aisyiah, BUEKA targets women's groups activily involved in Aisyiah Quranic reading circles. Through their participation in this circles and communities, women and mothers are not only benefiting from the Islamic teachings taught at the forum, but they are also organized collectively in income generating activities. The program (2011-2015) is also complemented with the establishment of As-Sakinah Cooperative, in 11 provinces both primary cooperative (164 cooperatives), 132 cooperative groups, pioneering cooperative (276 cooperatives), and 2.460 families. $^{49}$

The abovementioned creativity and initiative shown by Lazismu place the institution as pivotal wings of Muhammadiyah playing the role as agent of social change beyond the Muhammadiyah and Islam. This fact corresponds to Crutchfield idea that the role admitted by certain social organization like Muhammadiyah is a proxy agent brigding larger social change, not only for the organization, but also for the general public.

\footnotetext{
${ }^{47}$ Ibid., pp. 39-45.

${ }^{48}$ Ibid.

${ }^{49}$ Ibid.
} 
Borrowing Gramsci's analysis on culture's role in constructing identity and consensus, ${ }^{50}$ Muhammadiyah through Lazismu plays the role as an alternative power against to the State that has failed to empower society in several crucial fields of development. The deteriorated schools, marginalized farmers, discriminated women are among the homeworks that have not received proper attention by the State. In this situation, Muhammadiyah provides their contributions through various empowerment agenda and programs to uphold the dignity of the Nation and the humanity. For example, Lazismu in cooperation with Majelis Pemberdayaan Masyarakat (the Community Empowerment Board) continued to empower farmers through organic farming so that they do not depend on chemical fertilizers.

On the other hand, Lazismu also took collaboration with Muhammadiyah Disaster Management Center in coping with disaster prevention and mitigation. It is a part of Muhammadiyah social responsibility as organization to continue promoting social change for welfare and equity. Empowerment programs initiated under the management of Lazismu are a criticism, if not resistance, on the absences of the State and government in realizing community welfare. However, because Muhammadiyah is a moderate Islamic Civil Society Organization that upholds the vision of Pancasila (The Five Principles), the mandate of the Constitution/UUD 1994, and the dreams of the Nation forefathers, Muhammadiyah devotes themselves to challenge the State within the framework of fastabiq al-khayrät (contestation in good and honesty) in establishing prosperity. This is the manifestation of the organization as agent of transformation of naby munkar (preventing evil) in Islamic term.

To achieve the noble goals of Muhammadiyah in upholding fair and prosper Islamic community blessed by Allah. Lazismu promotes open and progressive stand and without a doubt utilizes organization and business management as tools to achieve goals. Such an effort is in line with the thoughts of Foster, Kim and Christiansen, as well as Frances that common management models applied in business and other professional organizations may also be adopted and adapted by non-profit organizations. Therefore, efficiency in the process and effectiveness in achieving goals are patterns that are not too difficult to find in nonprofit organizations. In this case, Lazismu as a philantrophic institution that manages zakat, infak and sadaqah as well as other contribution

${ }^{50}$ Antonio Gramsci, Quintin Hoare, and Geoffrey Nowell-Smith, Selections from the Prison Notebooks of Antonio Gramsci (New York: International Publishers, 1971). 
from donors and benefactors acts beyond collecting funds to does not only work as collector of donation, but also commiting modern and progressive planning, implementation, monitoring and evaluation to multiply benefit of the funds. Lazismu is not a traditional zakat collector that only works to distribute the funds received to those entitled of receiving them without considering midterm and longterm impact to prosperity and social justice. On the contrary, Lazismu is a accountable and professional 'amil especially in the process of capitalization of the philantrophic funding and social capital in a form of human resources and networks to measurable and systematic empowerment and welfare. ${ }^{51}$

"The Capitalization" of material assets and social capital under professional management and amana principle is solely aimed to enhance quality of management of Zakat, Infaq and Sadaqah (ZIS) that is amana (trustworthy), professional and transparent; enhance utilization of ZIS in creative, innovative, and productive way; and improve services to benefactors. ${ }^{52}$ The three missions guide the creativity, innovation, and mobilization of resources by Lazismu.

Last but not least, Lazismu has uniqueness in mobilizing the philantrophic funds. While Lazismu stated in their planning and scenario formulated in 2010 that they will continue to create profit business to develop the philanthropy, ${ }^{53}$ this plan has not yet placed as priority. Lazismu currently focuses and scenario of "transforming mustahiq (people who are entitled to receive zakat) to mu₹akkiz (zakat payer)". Management of Lazismu chooses this method of paying zakat through Lazismu instead of "profit sharing" that is considered provisional. Therefore, farmers" empowerment program for instance, is aimed to support facilitation, advocacy, training on farming, and provision of material capital. Once the farmers harvest their crop, they are obliged to pay zakat. The zakat is suggested to be paid at Lazismu both at regional and central office of the institution. Similar method is also applied in other programs such as empowerment of women and youth entrepreneurship. Lazismu programs are oriented to transform people at the receiving end of zakat to become the giving end, to transform consumptive activities into productive activities, and from receiving to giving. This way, the transformation uplifts not only the prosperity but also the dignity of the program beneficiaries.

${ }^{51}$ Lembaga Amil Zakat Infaq, Memberi untuk. Negeri, p. 8.

${ }^{52}$ Ibid., p. 9.

${ }^{53}$ Khoirul Muttaqin, interview (30 Jun 2015). 
Lazismu and Remaking the Muhammadiyah's New Way of Philanthropy

\section{The Bridge between Generosity and 'Amal Sälih (Good Deeds)}

Furthermore, we consider it necessary to explore spirit and motive underlying the Lazismu philantrophic movements as described above. The generosity and philanthropy in Islamic ethics are found in the teaching of compassion. The moral of $i b s a n$ describes the importance of a servant of God to mirror the qualities of God Takhallaqui bi akhläq Alläh is the moral of ihsan taught by Prophet Muhammad. Two of the qualities of God included in al-asmä' al-husnä (the best names of God) directly related to generosity and philanthropy are al-Rabmān (Most Benevolent) and al-Rabim (Most Merciful). KH. Ahmad Dahlan referred to it as theology of compassion as explained in previous part. As God is the Most Benevolent and Most Compassionate, the servant of God should also be compassionate to others especially to the under privilege in the community. ${ }^{54}$

Muhammadiyah through Lazismu represents the middle way (wasattiyya) in giving the meaning to generosity and philanthropy based on zakat, infaq, sadaqah and other contributions. Within the framework of amāna, generosity and philanthropy as manifestation of compassion needs to be managed responsibly and in two dimensions. Generosity manifests the compassion of God for the world Generosity and at the same time the manifestation of compassion will have eschatological impact for the ones sharing the compassion in the hereafter. ${ }^{55}$ Hence, the 'amil institution like Lazismu is responsible to expand both earthly and heavenly dimensions of the compassion.

Hence, the generosity and philanthropy perspective should assume to protect the best interest of the community and to protect humanity from profit cynicism, egocentric consumerism, narcissism, and accumulation of wealth for personal interest on the basis of income, social status, ethnicity, and other discriminatory factors. In the tradition of compassion theology and al-Mã $\bar{u}$ in theology developed by Muhammadiyah, compassion is not only described as human kindness. It also contains qualities of heavenly values. ${ }^{56}$ This idea is clear at least in the basmala sentence at the beginning of every surah/chapter in the Quran. The sentence is read "In the Name of Allah Most Benevolent and Most Compassionate." Both heavenly qualities can also be found in

${ }^{54}$ Azaki Khoiruddin, Teologi al-'Ashr: Etos dan Ajaran KH. A. Dablan yang Terlupakan (Yogyakarta: Suara Muhammadiyah, 2015), pp. 80-92.

${ }^{55}$ Ibid.

${ }^{56}$ Ibid., pp. 99-105. 
the 99 Best Names of Allah.

In the tradition of Islamic theology, compassion is also described as a kindness that helps us as social being to avoid destruction in our interactions with others. ${ }^{57}$ The idea is that people may not focus on their personal interest and gain or the interest of their group in their social interactions. In this case, Muhammadiyah and Lazismu institutionalized

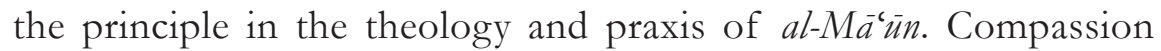
therefore is represented as the foundation for community participation in philanthropy that is all kinds of volunteer work committed to expect only the mercy of God.

In the tradition of Islamic theology about charity and voluntarism in humanitarian works, personal experience, struggle, and pain play a central role. Experience of despair is considered as one of the factors encouraging individuals to participate in charity and humanitarian activities. This experience invites people to help others in similar situation. We certainly can gain information about despair and difficulties experienced by others through various channels of information, but personal experience is considered as more powerful in raising our awareness on having none. The al-Māiun theology has developed a form of awareness and solidarity of people of faith to commit good deeds to help them who are in need. The point of departure lies in the our proximity to the reality surrounding us instead of to the reality that we observe from afar. $A l-M \bar{a}^{-} \bar{u} n$ invites us to emphatize with other despairs and scarcities. ${ }^{58}$

Generosity, philanthropy, and willingness to participate in voluntary works are the beginning of kindness and compassion. Through these works, inviduals show emphaty and solidarity with one another. Lazismu has adequate 'amil (zakat manager) resources to mobilize the volunteer works. They are the people who are willing and able to address humanitarian, education, health, empowerment issues at all level; paradigm, experience, and knowledge despite of continuous need to build and improve their skill and knowledge. ${ }^{59}$

The volunteerism of Lazismu resources that consist of young passionate activists with willpower to fight for the cause of the institution mobilizes Lazismu and Muhammadiyah. Wali amāna (board of advisory),

${ }^{57}$ Ibid., pp. 99-105.

${ }^{58}$ Zakiyuddin Baidhawy, Teologi Neo al-Ma'un: Manifesto Islam Menghadapi Globalisasi Kemiskinan Abad 21 (Jakarta: Civil Islamic Institute, 2009), pp. 115-20.

${ }^{59}$ Muttaqin, interview (30 Jun 2015). 
Lazismu and Remaking the Muhammadiyah's New Way of Philanthropy board of supervisory, and board of executives also consist of academics and activists who work voluntarily based on their deep concern on humanities issue and their hight morality to develop innovative and creative programs. ${ }^{60}$

It is undeniable that volunteerism and the will to serve has provided abundant resources to serve various works of the organizations, from dai working in remote areas in Indonesia for moral, religious, humanitarian, and economic missions, the teachers of Muhammadiyah with their generosity in contributing their time and knowledge for the betterment of education, to volunteers working for disaster relief and eradication of poverty and backwardness. Lazismu volunteers are ranging from academics, environmental activists, and travellers to psychologists and engineers working to mobilize Muhammadiyah Disaster Management Center (MDMC) to provide emergency response, evacuation, recovery, and post-disaster rehabilitation. In addition, the institution also receives contributions from doctors, students of Vocational School, baby sitters, and women of Aisyiyah who work at public kitchen. ${ }^{61}$

\section{E. Concluding Remarks}

Helping others is not only aimed at accumulating personal good. In addition to individual gain, compassion should serve as the basis to build social network that functions in the society. Compassion in this context is established on the basis of equality where through the assistance provided, the poor and the underprivilige can improve their wellbeing and stand as equal to other members of society. From this perspective, compassion and assistance are good deeds serving as the basis for active intiatives to help them at "situational inequalities." 'This means that they are facing certain problems that place them as unequal to others. We, therefore, need to know who are eligible for this help according to the Quran to share our collective compassion.

Muhammadiyah within a decade of leadership of Din Syamsudin has come up with a formula of new philanthropy in a form of Lazismu, a philanthropy that is smart in responding to the spirit of the era. It is a transformative philanthropy that has been successful in transforming charity based generosity into creative-innovative good deeds. The vision is a long term one that is to empower the poor, to transform receiver

${ }^{60}$ Ibid.

${ }^{61}$ Muttaqin, interview (3 Dec 2015). 
Zakiyuddin Baidhawy

to giver, to turn a hand that is receiving to a hand that is giving. All of them are designed under the flag of progressive and enlightening Islam. 
Lazismu and Remaking the Muhammadiyah's New Way of Philanthropy

\section{BIBLIOGRAPHY}

“110 Ribu Ruang Kelas SD Kondisinya Rusak Berat", RMOL.co, 6 Dec 2012, http://www.rmol.co/read/2012/02/12/54577/110-RibuRuang-Kelas-SD-Kondisinya-Rusak-Berat-, accessed 31 Oct 2015.

Abdullah, Irwan, The Muslim Businessmen of Jatinom: Religious Reform and Economic Modernization In a Central Javanese Town, Ph.D Dissertation, Amsterdam: Universiteit Van Amsterdam, 1994.

Alawiyah, Tuti, "Religious Non-Governmental Organizations and Philanthropy In Indonesia", Indonesian Journal of Islam and Muslim Societies, vol. 3, no. 2, 2013, pp. 203-21[http:/ /dx.doi.org/10.18326/ ijims.v3i2.203-221].

Alter, S.K., "Social Enterprise Models and Their Mission and Money Relationships", in Social Entrepreneurship: New Models of Sustainable Social Change, ed. by Alex Nicholls, New York: Oxford University Press, 2006.

"Anggaran Dasar | Pimpinan Pusat Muhammadiyah", Muhammadiyah.or.id, http://www.muhammadiyah.or.id/id/content-51-det-anggarandasar.html, accessed 31 Oct 2015.

Anheier, Helmut K. and Jeremy Kendall (eds.), Third Sector Policy at the Crossroads: An International Nonprofit Analysis, New York: Routledge, 2001.

Bacq, Sophie and Frank Janssen, "The Multiple Faces of Social Entrepreneurship: A Review of Definitional Issues Based on Geographical and Thematic Criteria", Entrepreneurship \& Regional Development, vol. 23, no. 5-6, 2011, pp. 373-403 [http://dx.doi. org/10.1080/08985626.2011.577242].

Baidhawy, Zakiyuddin, Teologi Neo al-Ma'un: Manifesto Islam Menghadapi Globalisasi Kemiskinan Abad 21, Jakarta: Civil Islamic Institute, 2009.

Blair, Tony, The Third Way: New Politics for the New Century, London: The Fabian Society, 1998.

----, Private Action, Public Benefit: A Review of Charities and the Wider not-for Profit Sector, London: Cabinet Office Strategy Unit, 2002.

Blair, Tony, Ken Coates, and Michael Barratt Brown, Third Way ... Where to?, Nottingham: Spokesman for Socialist Renewal, 2001.

Burhani, Ahmad Najib, "Makna Teologi al-Ma'un di Dua Generasi 
Zakiyuddin Baidhawy

Muhammadiyah", Suara Muhammadiyah, vol. 13, no. 98, 2013.

Crutchfield, Leslie R., Forces for Good: The Six Practices of High-Impact Nonprofits, San Francisco: Jossey-Bass, 2012.

Deakin, Nicholas, "Putting Narrow Mindedness Out of Countenance": The UK Voluntary Sector in the New Millennium”, 2000, http:/ / eprints.lse.ac.uk/29034/.

Dees, J. Gregory, "The Meaning of 'Social Entrepreneurship," reformatted and revised, May 30, 2001. https:/ / centers.fuqua.duke. edu/case/wp-content/uploads/sites/7/2015/03/Article_Dees_ MeaningofSocialEntrepreneurship_2001.pdf.

Defourny, Jacques, "From Third Sector to Social Enterprise", in The Emergence of Social Enterprise, ed. by Carlo Borzaga and Jacques Defourny, London: Routledge, 2001.

Defourny, Jacques and Marthe Nyssens, "Conceptions of Social Enterprise in Europe: A Comparative Perspective with the United States", 8th ISTR International Conference and 2nd EMES-ISTR European Conference, Barcelona, 2008.

Egger, Robert, Begging for Change: The Dollars and Sense of Making Nonprofits Responsive, Efficient, and Rewarding for All, New York: Harper Collins, 2004.

Fanani, Ahmad Fuad, "Muhammadiyah Sebagai Gerakan Ilmu", Republika, 18 May 2010.

Foster, William Landes, Peter Kim, and Barbara Christiansen, "Ten Nonprofit Funding Models", Stanford Social Innovation Review, vol. 7, no. 2, 2009, pp. 32-9.

Fowler, Alan, "NGDOs as a Moment in History: Beyond Aid to Social Entrepreneurship or Civic Innovation?", Third World Quarterly, vol. 21, no. 4, 2000, pp. 637-54 [http:/ /dx.doi.org/10.1080/713701063].

Frances, Nic, The End of Charity: Time for Social Enterprise, Crows Nest: Allen \& Unwin, 2008.

Geertz, Clifford, The Religion of Java, Chicago: University of Chicago Press, 1976.

Giddens, Anthony, The Third Way and its Critics, Cambridge: Polity Press, 2000.

Gramsci, Antonio, Quintin Hoare, and Geoffrey Nowell-Smith, Selections from the Prison Notebooks of Antonio Gramsci, New York: International 
Lazismu and Remaking the Muhammadiyah's New Way of Philanthropy Publishers, 1971.

Grove, Andrea and Gary A. Berg (eds.), Social Business Theory, Practice, and Critical Perspectives, California: California Institute for Social Business California State University Channel Islands, 2014.

Hale, Sarah, Will Leggett, and Luke Martell (eds.), The Third Way and Beyond: Criticisms, Futures and Alternatives, Manchester: Manchester University Press, 2004.

Kerlin, Janelle A., "Social Enterprise in the United States and Europe: Understanding and Learning from the Differences", Voluntas: International Journal of Voluntary and Nonprofit Organizations, vol. 17, no. 3, 2006, pp. 246-62 [http://dx.doi.org/10.1007/s11266-0069016-2].

Khoiruddin, Azaki, Teologi al-'Ashr: Etos dan Ajaran KH. A. Dablan yang Terlupakan, Yogyakarta: Suara Muhammadiyah, 2015.

Latief, Hilman, Melayani Umat: Filantropi Islam dan Ideologi Kesejabteraan Kaum Modernis, Jakarta: PT Gramedia Pustaka Utama, 2010.

----, "Islamic Philanthropy and The Private Sector in Indonesia", Indonesian Journal of Islam and Muslim Societies, vol. 3, no. 2, 2013, pp. 175-201 [http://dx.doi.org/10.18326/ijims.v3i2.175-201].

----, Aksi Bersama untuk Sesama: Perilaku dan Potensi Filantropi Warga Muhammadiyah, Yogyakarta: LP3M UMY, Program Studi Muamalah, Ekonomi dan Perbankan Islam Fakultas Agama Islam UMY \& Lazismu, 2015.

Lembaga Amil Zakat Infaq dan Shadaqah (Lazismu) Pimpinan Pusat Muhammadiyah, Memberi untuk. Negeri: Annual Report 2010-2014, Yogyakarta: Muhammadiyah, 2010.

Mair, Johanna and Ignasi Martí, "Social Entrepreneurship Reserach: a Source of Explanation, Prediction and Delight", Journal of World Business, vol. 41, no. 1, 2006, pp. 36-44 [http:/ /dx.doi.org/10.1016/j. jwb.2005.09.002].

Martin, Roger L. and Sally Osberg, "Social Entrepreneurship: The Case for Definition", in Stanford Social Innovation Review, Leland Stanford Jr. University: Spring, 2007, pp. 29-39.

Masmulyadi, "Muhammadiyah dan Rekonstruksi Mental Entrepreneurship", khittah.co, http:/ / www.khittah.co/muhammadiyah-dan-rekonstruksimental-entrepreneurship/1327/, accessed 6 Jun 2015. 
Zakiyuddin Baidhawy

Nakamura, The Crescent Arises Over the Banyan Tree: A Study of the Mubammadiyah Movement in a Central Javanese Town, C.1910-2010, Singapore: Institute of Southeast Asian Studies (ISEAS), 2012.

Nicholls, Alex and Cho H A., "Social Entrepreneurship: The Structuration of a Field", in Social Entrepreneurship: New Models of Sustainable Change, ed. by Alex Nicholls, Oxford: Oxford University Press, 2008.

Peacock, James L., Purifying the Faith: the Muhammadijah Movement in Indonesian Islam, California: The Benjamin/Cummings Publishing Company, 1978.

Romano, Flavio, "Clinton and Blair: The Economics of the Third Way", Journal of Economic and Social Policy, vol. 10, no. 2, 2006, pp. 79-94.

Setiawan, Benni, “Trisula Abad Kedua", SINDOnews.com, 4 Aug 2015, http:// nasional.sindonews.com/read/1029056/18/trisula-abadkedua-1438651728, accessed 31 Oct 2015.

Wei-Skillern, Jane et al., Entrepreneurship in the Social Sector, Los Angeles: SAGE Publications, 2007. 